\title{
Analyzis of permeabilities of the clayey sediments of Gbédji-Kotovi village in Benin for its valorization in the construction of dikes.
}

\author{
${ }^{1}$ Kassa Issifou MOUNOU SAMBIENI, ${ }^{2}$ François de Paule CODO, ${ }^{3}$ Crépin ZEVOUNOU \\ ${ }^{1}$ International Chair in Mathematical Physics and Applications (ICMPA-UNESCO Chair), University of Abomey-Calavi, 072 BP 50 Cotonou, Republic of Benin, \\ ${ }^{2}$ Water National Institute (INE), University of Abomey-Calavi, 01 BP: 572, Republic of Benin, \\ ${ }^{3}$ Laboratory of Testing and Research in Civil Engineering (LERGC), BP 7050 Cotonou, Republic of Benin
}

Correspondence Author: François de Paule CODO, University of Abomey-Calavi, National Water Institute (INE), 01 BP: 572 , Republic of Benin, E- mail: fdepaule2003@yahoo.fr.

Received date: 22 December 2017, Accepted date: 22 January 2018, Online date: 28 February 2018

Copyright: (C) 2018 François de Paule CODO. This is an open-access article distributed under the terms of the Creative Commons Attribution License, which permits unrestricted use, distribution, and reproduction in any medium, provided the original author and source are credited.

\begin{abstract}
Background: In the watersupply mobilization with dikes, embankment or earth dams, it is necessary to find soils, excavated materials for their realization, having a low permeability. Objective: This study aims to determine the permeability of swelling clay soils for the construction of dikes, embankment or earth dams. Results: Their calculation is done in-situ, using the Muntz double ring method and provide low and medium permeability varying between $1.62 .10^{-5} \mathrm{~m} / \mathrm{s}$ and $2,04.10^{-5} \mathrm{~m} / \mathrm{s}$. Taking into account parameters of nature and soil condition in place, it is indirectly measured permeabilities. The last experiment uses the oedometric coefficients of consolidation through Casagrande and Taylor models to calculate the vertical permeability. Conclusion: The two models got possibility to obtain the permeabilities between $9,07 . .10^{-12} \mathrm{~m} / \mathrm{sand} 2.59 .10^{-9} \mathrm{~m} / \mathrm{s}$. Overall, the low and medium permeabilities of Gbédji-Kotovi clay sediments characterize an impervious or very low permeable clay soil that is likely to act as a watertight backfill for building dikes.
\end{abstract}

Keywords: Permeability, consolidation, infiltration, oedometer, permeameter, infiltrometer.

\section{INTRODUCTION}

The depression of the Lamais characterized by outcropping marl and limestone clays of the Paleocene and Eocene formations, presenting physical and hydraulic properties that change according to the nature of their drainage H.A. AZONTONDE, 1991; B. Iheta et al (1982). Especially, the smectitic clayey soils of Gbédji-Kotovi dominated by the beidelite mineral, Etienne SAGBO, 2015, are very heterogeneous and swelling: Kassa Issifou MOUNOU SAMBIENI and al., 2017; Also, the design of small dams requires knowledge of some preliminary technical parameters related to permeability, grain size and geotechnical behavior. The determination of the permeability is therefore an essential step to validly conclude on the hydraulic functionality of these dikes. Several authors recognize that laboratory tests can greatly underestimate the hydraulic conductivity of a soil. This difference occurs when the construction technics used in-situ favor the formation of macropores in the soil, which regulate the flow through the soil. Larger samples better represent the distribution of desiccation cracks and other macroporosities in the soil, while small samples (diameter less than $15 \mathrm{~cm}$ ) used in the laboratory contribute to underestimating the hydraulic conductivity in situ by factors ranging from 10 to 10,000: MARION PEREZ (2013); François Duhaime, 2012.Thus, in this study, direct and indirect measurements of vertical permeability in the laboratory will be verified by the permeability in-situ (though infiltration measurements). The ultimate goal is to provide hydraulic data for the use of Gbédji-Kotovi clays in the case of construction of dams and small dikes and to establish the relationship between hydraulic conductivity and certain physical properties of these clay materials.

Nomenclature:

$\mathrm{H}$ : Total height ofwater circulation over the cylindrical tube (m)

$\mathrm{K}$ : Permeability coefficient of Darcy $(\mathrm{m} / \mathrm{s})$

$K_{v}$ : Vertical hydraulic conductivity $(\mathrm{m} / \mathrm{s})$

$\mathrm{L}$ : Cylinder length $(\mathrm{m})$

$\mathrm{Q}$ : Flow rate $\mathrm{Q}\left(\mathrm{m}^{3} \cdot \mathrm{s}^{-1}\right)$

$\mathrm{S}$ : Area of the cylinder $\left(\mathrm{m}^{2}\right)$

$\mathrm{V}$ : Volume of infiltrated water $\left(\mathrm{m}^{3}\right)$

$\mathrm{R}$ : Radius of the cylinder (m)

$\mathrm{x}$ : Evaporation factor $(\mathrm{cm} / \mathrm{s})$

$\mathrm{t}$ : Time (sec)

A: Cylinder cross-section $\left(\mathrm{m}^{2}\right)$

a: Section of the tube where the readings take place.

$\varepsilon_{x}$ : Horizontal deformation (mm)

$\varepsilon_{y}$ : Radial deformations (mm) 
Citation:François de Paule CODO, 2018. Analyzis of permeabilities of the clayey sediments of Gbédji-Kotovi village in Benin for its valorization in the construction of dikes. Journal of Applied Sciences Research., 14(1): 45-56.

$\sigma^{\prime}:$ Effective stress $(\mathrm{kPa})$

$\varepsilon_{z}:$ Axial deformation $(\mathrm{mm})$

$C_{c}:$ Compression index

$\sigma_{v o}^{\prime}:$ Effective stress of the soil in situ $(\mathrm{kPa})$

$\Delta \mathrm{H}$ : The variation of thickness $(\mathrm{mm})$

$\sigma_{g}$ : Swelling pressure $(\mathrm{kPa})$

$m_{v}$ : Compressibility coefficient

E': Oedometric module

$C_{v}$ : Coefficient of consolidation

Tv: Time factor

$C_{v n}:$ Coefficient of consolidation corrected

Presentation of the study area:

The clayey deposit of Gbédji-Kotovi is located between $2^{\circ} 00$ 'and $2^{\circ} 02^{\prime}$ east longitude and between $6^{\circ} 40$ 'and $6^{\circ} 42^{\prime}$ north latitude in the Coastal Sedimentary Basin. Maximum temperatures rarely exceed $40^{\circ} \mathrm{C}$ and minimum fall below $14^{\circ} \mathrm{C}$, with rainfall of $1,100 \mathrm{~mm}$ per year. The drainage axes are dominated by the valley of the Couffo River (Figure 1).The area is dominated by the mio-Pliocene deposits of the quarternary relying on the middle Eocene kaolin clays. They may have to be crossed before accessing and capturing the Upper Palaeocene (variable thickness) aquifers whose recharges would come from rain, through drainage, M. Slansky, 1962.

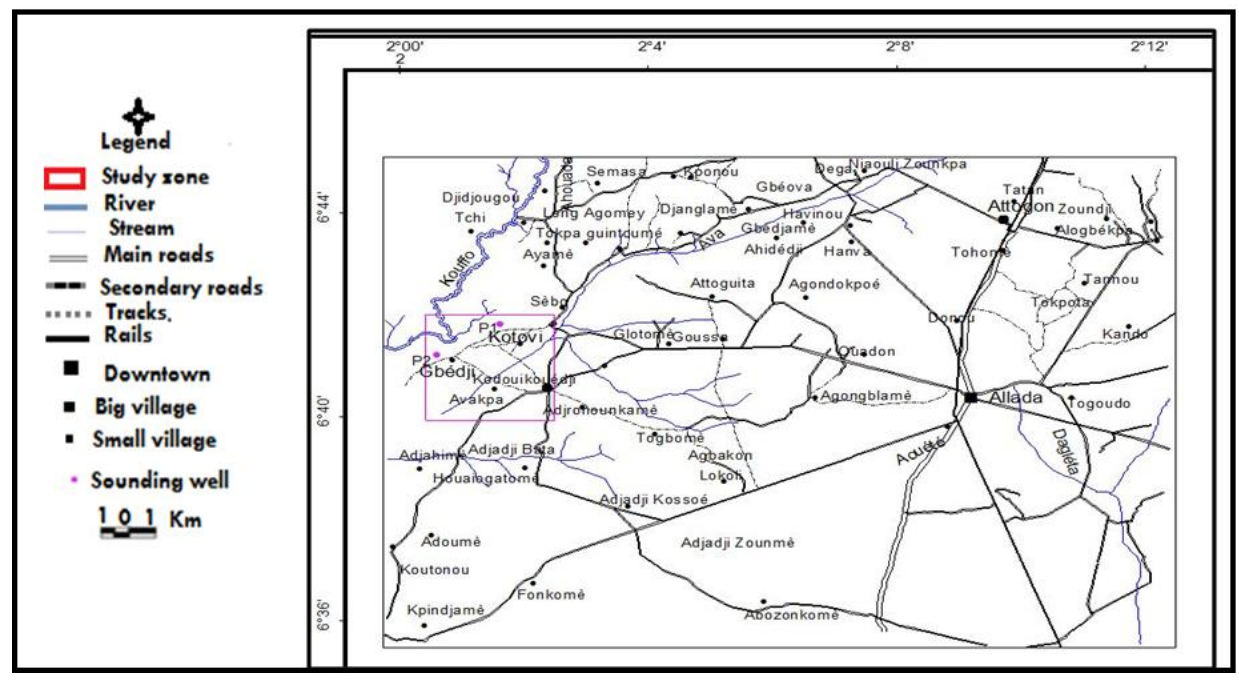

Fig. 1: Localisation of Gbédji-Kotovi clayey.

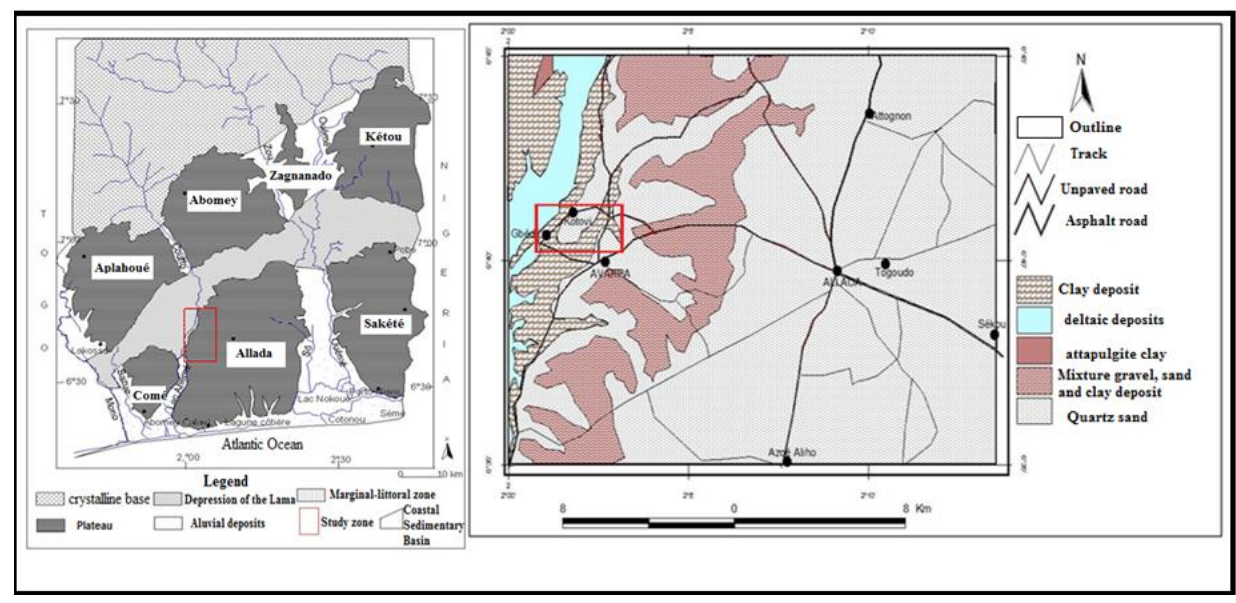

Fig. 2: Géomorphlogical (left) and geological (right) maps of Gédji-Kotovi area.

\section{MATERIALS AND METHODS}

Measurement of vertical permeability in situ, using the method of double ring of Muntz:

We consider a cylindrical tube with a loose rock over a height in which water is circulated over a total height $\mathrm{H}\left(h_{1}-h_{2}\right)$. When the medium is saturated with water, the following Darcy's simplified equation is written:

$\mathrm{Q}=\mathrm{K} . \mathrm{S} \frac{\mathrm{h}_{1}-\mathrm{h}_{2}}{\mathrm{~L}}$

The method is based on the determination of the vertical velocity of a water flow, through a soil, from Darcy's law: J. COLOMBANI et al., 1973. The validity of Darcy's law has been verified for compacted clays, based on permeability tests, Tavenas et al., 1983 , for hydraulic gradient values between 0.1 and 50 . This is therefore appropriate actually in-situ study of clays. After stabilization of the speed, the volume of infiltrated water V is measured as a function of time t. In this method, there is uncertainty about the value of h, P.Boivin, Orstom Bondy, 1991). To overcome this problem, we consider that the hydraulic gradient is equal to 1 , that is to say that we consider that $\mathrm{h}$ is negligible in front of $\mathrm{L}$. It is also very important to note that the measurements made are measures of saturated 
Citation:François de Paule CODO, 2018. Analyzis of permeabilities of the clayey sediments of Gbédji-Kotovi village in Benin for its valorization in the construction of dikes. Journal of Applied Sciences Research., 14(1): 45-56.

hydraulic conductivities, the soils having been previously saturated several times before measuring the speed of infiltration of the water through the ring: Luc Lepetit, 2002). Since the flow $\mathrm{Q}$ is known, the infiltration taking place along the surface $\mathrm{S}$ equal to the section of the cylinder and the hydraulic gradient (equal to 1 ), the flow is expressed by the relation:

$\mathrm{Q}=\frac{\mathrm{V}}{\mathrm{t}}$

By applying the law of Darcy (1) and (2), we have:

$\mathrm{K}=\frac{\mathrm{V}}{\mathrm{S.t}}$.

Where the flow rate $\mathrm{Q}\left(\mathrm{m}^{3} . \mathrm{s}^{-1}\right)$ is proportional to $\mathrm{S}$ and $\Delta \mathrm{H}$ and inversely proportional to $\mathrm{L} ; \mathrm{k}$ corresponds to the permeability coefficient of Darcy (m.s-1); $\mathrm{S}$ is the area $\left(m^{2}\right) ; \Delta \mathrm{H}$ is the pressure drop $(\mathrm{m})$. The permeability is defined by the intrinsic permeability value $\mathrm{K}\left(\mathrm{m}^{2}\right)$ or by the permeability coefficient associated with Darcy's law.

The mean value of equivalent permeability in the vertical direction $K_{v}$ is:

$K_{v}=\frac{\sum_{1}^{\mathrm{n}} \mathrm{Hi}}{\sum_{1}^{\mathrm{n}} \mathrm{Hi} / \mathrm{ki}}$

For this method, the precautions for use are: i) the test surface must be flat and almost horizontal. It must also be stripped to reach a material unaltered by weather conditions; ii) It is necessary to measure the temperature of the water to allow the correction of the results. In this studi, the temperature is supposed constant and equal to $20^{\circ} \mathrm{C}$; iii) the device must be covered to prevent evaporation of water which may be important when tested for more than one hour.

Direct measurement of vertical permeability in the laboratory, using the Eijkelkamp brand open-system Permeameter:

The hydraulic conductivities of pre-saturated samples in the cylinders are determined in the laboratory using an open system permeameter of the Eijkelkamp brand. Using the formulas, the permeability coefficient has been determined
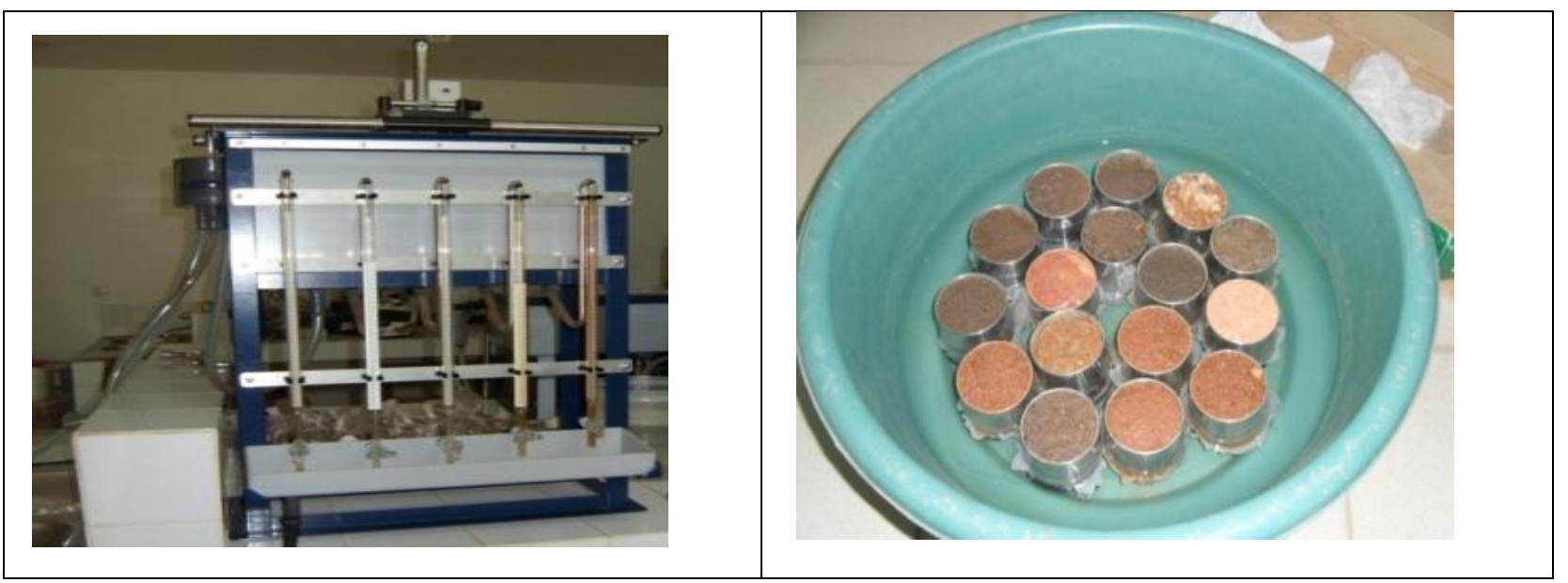

Fig. 3: Eijkelkamp open-system permeameter (left) and pre-saturation soil sample cylinders (right).

Two types of equipments are commonly used to measure the permeability $\left(K_{v}\right)$ in the laboratory:

$\checkmark \quad$ For High Permeability Samples or Samples with intermediate permeability, the height of water in the cylinder holder is the same as in the container after one hour or several hours:the Constant Load Method is used, and the formula applied is as follows:

$\mathrm{K}_{\mathrm{v}}=\frac{V \cdot L}{A \cdot t \cdot h}$.....

Where $\mathrm{L}$ is the cylinder length (equal to $5 \mathrm{~cm}$ ); $\mathrm{t}$ is the time (sec); $\mathrm{R}$ is the radius of the cylinder; $\mathrm{A}$ is the cylinder cross-section; $\mathrm{V}$ is the cylinder volume; $\mathrm{h}$ is the difference in load.

$\checkmark \quad$ For Samples with low permeability, where water appears above the sample after $24 \mathrm{~h}$, the Load reduction method is used and the formula applied is as follows:

$\mathrm{K}_{\mathrm{v}}=\frac{a \cdot L}{A \cdot\left(t_{2}-t_{1}\right)} \cdot \ln \frac{h_{1}}{h_{2}}+\frac{x \cdot a \cdot L}{A \cdot \sqrt{\left(h_{1}-h_{2}\right)}}$

Where $\mathrm{L}$ is the cylinder length; $\mathrm{R}$ is the radius of the cylinder; $\mathrm{x}$ is theevaporation factor $(\mathrm{cm} / \mathrm{s}) ; \mathrm{t}$ is the time $(\mathrm{sec})$.

Note that to have a good accuracy, it is necessary to have a tube of small section but in which the capillary effects must remain negligible. Formula (6) becomes:

$\mathrm{K}_{\mathrm{v}}=2,3 \frac{\mathrm{a}}{\mathrm{A}} \frac{\mathrm{L}}{\left.\mathrm{t}_{1-} \mathrm{t}_{2}\right)} \log \frac{\mathrm{h}_{1}}{\mathrm{~h}_{2}}$

This test procedure is generally used for fine soils withrather low permeability coefficients $(<\mathrm{E}-7 \mathrm{~m} / \mathrm{s})$. The soil to be studied is placed in thepermeameter (Figure 4). We measure the time needed for the water level to go downfrom level $h_{1}$ to level $h_{2}$. We are in the case of a one-dimensional flow, and wecan apply Darcy's law for each elementary interval of time $(t, t+d t)$. 


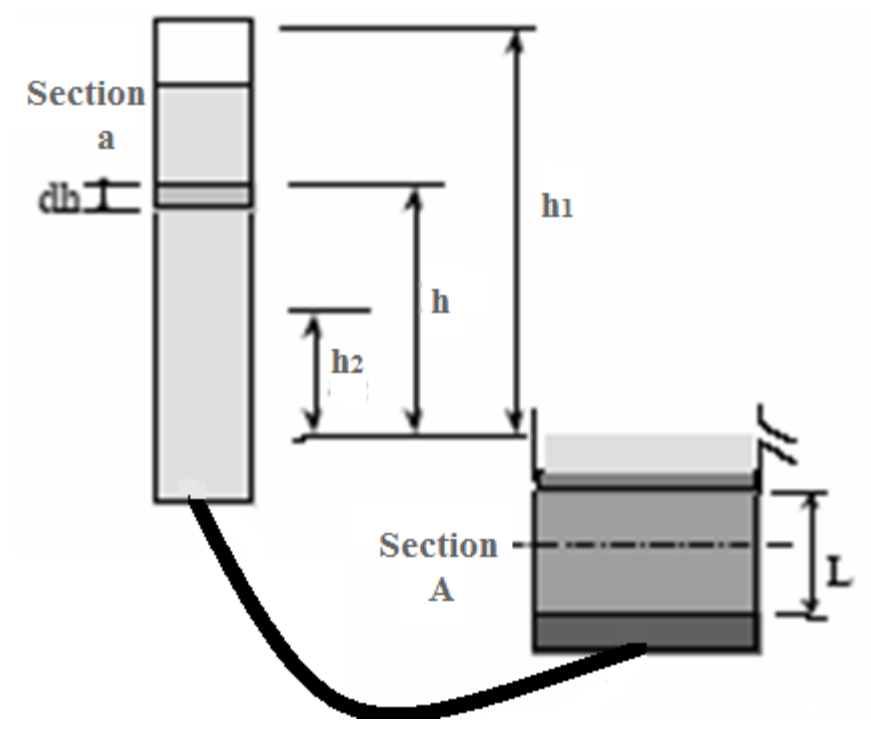

Fig. 4: Variable Load Test Procedure.

After applying the corresponding formulas, tree (03) different values of $K_{v}$ are obtained. Using these values, a curve is produced. The shape of this curve will determine which $\mathrm{K}_{\mathrm{v}}$ to choose:

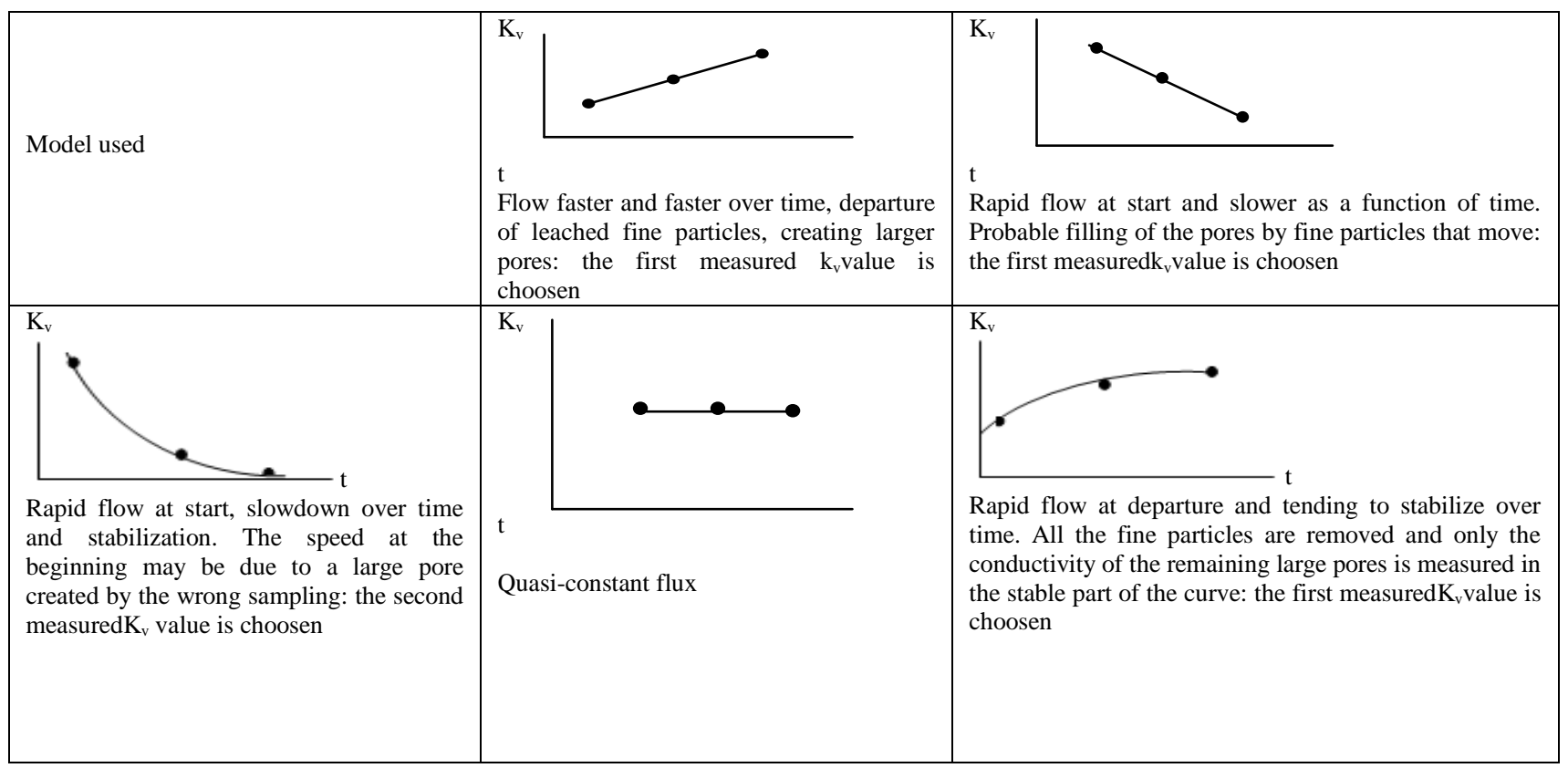

Fig.5: different shape of the curves with the choosen $\mathrm{K}_{\mathrm{v}}$

Indirect measurement of the vertical permeability in the laboratory, using the oedometric device:

The principle of the apparatus is reproduced in Figure 6. A soil sample is placed in a rigid cylindrical enclosure of circular section between two porous stones ensuring its drainage. A piston makes it possible to apply to the sample a constant uniform vertical stress for a given time: norme XP P94-090-1 (1997). The advantage of applying a vertical load on the upper surface of the sample is:

- To reduce the differential flow on the contour of the sample;

- To reproduce the loading conditions in situ;

- To follow the evolution of $K_{v}$ according to the void index or the degree of consolidation. So it is possible to establishcompressibility (voidersusconstraint) and consolidation (relative settlement versus log dependence) curves. To measure the permeability, the soil can be consolidated and the permeability is calculated from the consolidation rate:

$K_{v}=\frac{\mathrm{C}_{\mathrm{v}} \cdot \gamma_{\mathrm{w}}}{\mathrm{E}^{\prime}}$

Where $\mathrm{C}_{\mathrm{v}}$ is Oedometric modulus 
Citation:François de Paule CODO, 2018. Analyzis of permeabilities of the clayey sediments of Gbédji-Kotovi village in Benin for its valorization in the construction of dikes. Journal of Applied Sciences Research., 14(1): 45-56.

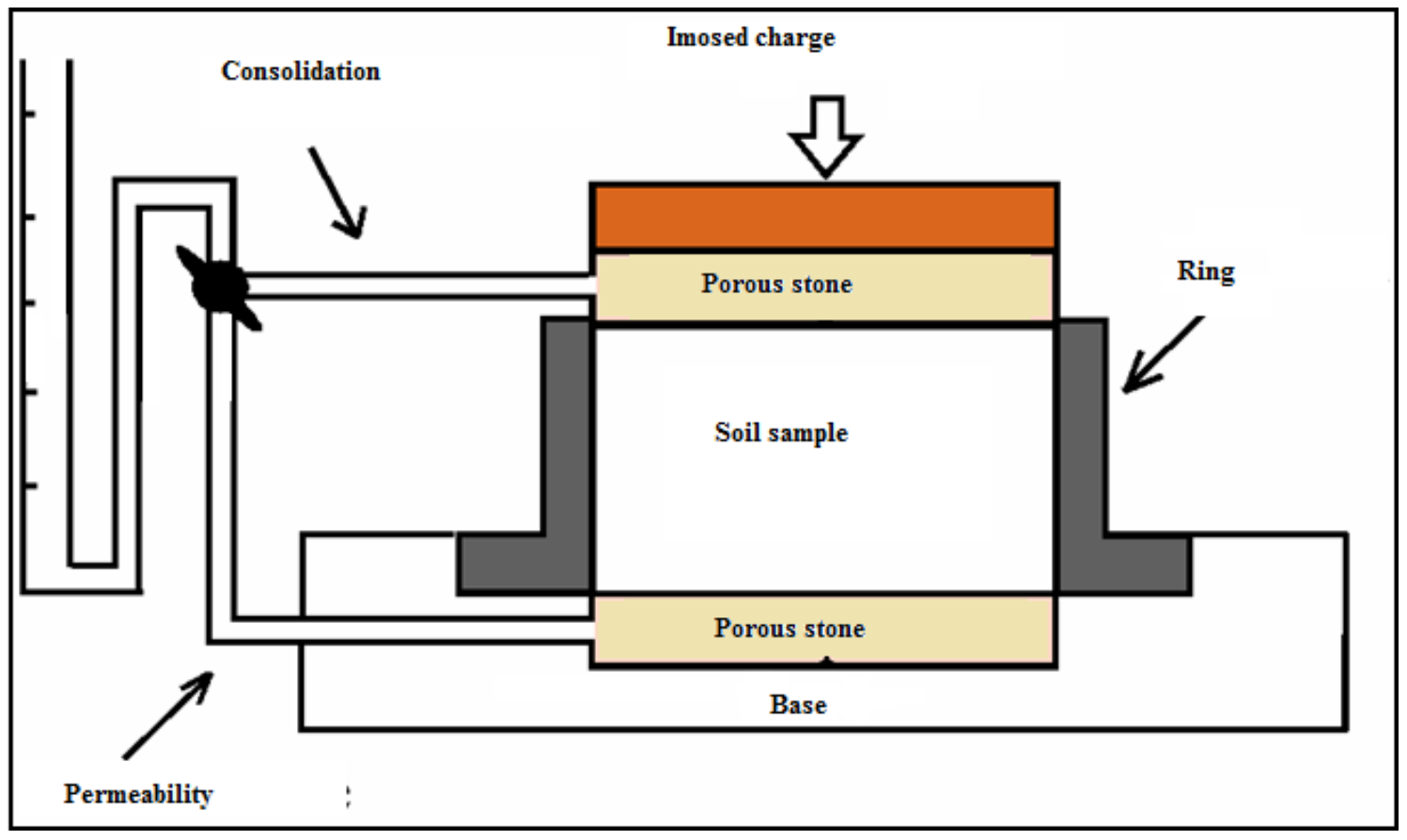

Fig.6: Oedometric test.

The fundamental hypothesis consists in admitting that there is no horizontal deformation (zero radial deformations):

$\varepsilon_{x}=\varepsilon_{y}=0$

Water and grains being incompressible, the deformations can only come from the movement of grains between them. The constitutive law is determined experimentally according to standard XP P 94-090-1, in two stages by means of a battery of several conventional odometers with weight loading. Each apparatus includes a cell and a charging frame. In the cell (of cylindrical shape, of section S and height H0), the soil sample to be studied is placed between two saturated porous stones in the cell (rigid metal mold and of the same internal diameter as the sample). The loading frame makes it possible to apply to the piston resting on the upper porous stone a constant load Q and to keep it constant for the desired time. The piston slides in the ring with little play and friction. Successive loadings of increasing weight are successively applied stepwise. The drainage system allows the water to evacuate from the sample along symmetrical ascending and descending vertical paths, while allowing the soil to remain saturated. The dissipation of the interstitial excess pressures which result from the drainage makes it possible to impose on the soils of effective stress $\sigma$ 'equal to the principal stresses applied $\sigma$ such that:

$\sigma_{v(n+1)}^{\prime}=2 \sigma^{\prime} v_{n}$

Comparators make it possible to measure the corresponding settlement $\mathrm{H}$ and thus to calculate the axial deformation:

$\varepsilon_{Z}=\frac{\Delta H}{H 0}$

The test provides two types of curves: a compressibility curve $\left[\mathrm{e}-\log \left(\sigma_{z}^{\prime}\right)\right.$ and a consolidation curve $\left[\left(\varepsilon_{\mathrm{z}}-\log (\mathrm{t})\right]\right.$. to determine the main deformation characteristics of the studied soil. the compression index is:

$C c=\frac{-\Delta e}{\Delta\left(l g \sigma^{\prime}\right)}$

The variation of thickness $\Delta \mathrm{H}$ (settlement) of a soil layer of thickness $\mathrm{H} 0$, when the effective stress passes from $\sigma_{v o}^{\prime}$ to $\sigma_{v o}^{\prime}+\Delta \sigma_{z}^{\prime}$ by the formula: $\Delta H=-H_{0 \cdot} \frac{C c}{1+e_{0}} \cdot \lg \left(1+\frac{\Delta \sigma_{z}^{\prime}}{\sigma_{v 0}^{\prime}}\right)$........

For a soil composed of several layers, the total settlement $(\mathrm{H})$ is equal to the sum of the settlements $(\mathrm{Hi})$ of the $\mathrm{n}$ considered layers:

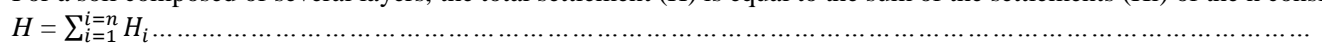

The compressibility curve makes it possible to do the graphical determination of the values of the preconsolidationpressure $\sigma_{P}^{\prime}$, the effective soil pressure insitu $\sigma_{V 0}^{\prime}$ and the swelling pressure $\sigma_{g}$.

The oedometric module, linking the deformations to the constraints, in a monoaxial law of behavior is:

$\Delta \sigma^{\prime}=-\mathrm{E}^{\prime} \cdot \frac{\Delta H}{H}$

$\mathrm{E}^{\prime}=-\frac{\sigma^{\prime}}{\frac{\Delta H}{H}}=-\frac{\Delta \sigma^{\prime}(1+e)}{\Delta e}=\frac{1+e}{C c} \cdot \frac{\Delta \sigma}{\lg \left(1+\frac{\Delta \sigma^{\prime}}{\sigma^{\prime}}\right)}=\frac{1}{m_{v}}$

We deduce:

$m_{v}=-\frac{\Delta e}{(1+e) \Delta \sigma^{\prime}}$

$m_{v}$ is thecompressibility coefficient

The curves of variations of the heights of the specimens as a function of time make it possible to calculate the coefficient of consolidation, for a saturated specimen, using two models.

i) Taylor model, following the square root of time;

$C_{V}=\frac{T_{v} \cdot h^{2}}{t}$...... 
Citation:François de Paule CODO, 2018. Analyzis of permeabilities of the clayey sediments of Gbédji-Kotovi village in Benin for its valorization in the construction of dikes. Journal of Applied Sciences Research., 14(1): 45-56.

Where $T_{V}=0.848$ for a degree of consolidation of $90 \%\left(t=t_{90}\right)$.

ii) Casagrande model, according to the logarithm of time:

$C_{V}=\frac{T_{v} \cdot h^{2}}{t}$........

Where $T_{V}=0.197$ for a degree of consolidation of $50 \%\left(t=t_{50}\right)$.

The theory of consolidationof Terzaghi has been generalized to three dimensions in order to determine the vertical permeability $K_{V}$. The general equation governing the flow is written in semi-polar coordinates:

$C_{r}\left(\frac{\partial^{(2(\Delta u)}}{\partial r^{2}}+\frac{1}{r} \frac{\partial(\Delta u)}{\partial r}\right)+C_{v} \frac{\partial^{2}(\Delta u)}{\partial z^{2}}=\frac{\partial(\Delta u)}{\partial t}$

Assuming that horizontal flow is prevented, vertical one-dimensional flow is obtained:

$C_{v} \cdot \frac{\partial^{2}(\Delta u)}{\partial z^{2}}=\frac{\partial(\Delta u)}{\partial t}$

For this type of flow, the time factor $T_{V}$ according to the two models used has the expression:

$T_{v}=\frac{C_{v}}{h^{2}}$

Where $\mathrm{h}$ is the drainage distance. For a charge increment from $\sigma_{n}$ to $\sigma_{n+1}$, we have:

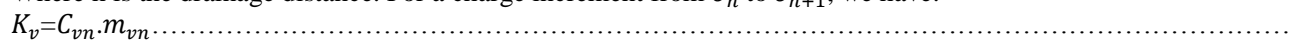

Where:

$m_{v n}=\frac{1}{1+e_{m n}}\left(\frac{e_{n-} e_{n+1}}{\sigma_{n}^{\prime}-\sigma_{n+1}^{\prime}}\right)$

Diagrams of the variation of the permeability as a function of the void index and those of the variation of the void index as a function of the load make it possible to establish the experimental law of the variation of the permeability as a function of the applied load and to make corrections on the $C_{v n}$ coefficient of consolidation corrected by means of relations:

$C_{v n}=\frac{K_{v}(1+e)}{0,454 C_{s} \gamma_{w}} \sigma^{\prime}$ pour $\sigma_{v 0}^{\prime}<\sigma^{\prime}<\sigma_{\mathrm{p}}^{\prime}$

And

$C_{v n}=\frac{K_{v}(1+e)}{0,434 C_{Y} \gamma_{w}} \sigma^{\prime}$ pour $\sigma_{\mathrm{p}}^{\prime}<\sigma^{\prime}$

\section{RESULTS AND DISCUSSION}

Measurementof the permeability $\left(K_{v}\right)$ in the laboratory with open-label permeameter from Eijkelkamp brand:

The tables $1 \mathrm{a}$ and $1 \mathrm{~b}$ resum the methods used and the chosen $K_{v}$ :

Table 1a: Methodechosed to measure $K_{v}$ of each sample

\begin{tabular}{|c|c|c|}
\hline Horizons & $K_{v}(\mathrm{~m} / \mathrm{s})$ & Method \\
\hline GK_0.1 & $4,42209 \mathrm{E}-05$ & In load \\
\hline GK_0.1 & $4,32082 \mathrm{E}-05$ & In load \\
\hline GK_0.1 & $4,17952 \mathrm{E}-05$ & In load \\
\hline GK_0.7 & $4,34548 \mathrm{E}-06$ & In load \\
\hline GK_0.7 & $4,01332 \mathrm{E}-06$ & In load \\
\hline GK_0.7 & $4,05077 \mathrm{E}-06$ & In load \\
\hline GK_1.0 & $2,01156 \mathrm{E}-09$ & reduction of volume \\
\hline GK_1.5 & $1,36002 \mathrm{E}-07$ & In load \\
\hline GK_1.5 & $1,10929 \mathrm{E}-07$ & In load \\
\hline GK_1.5 & $1,9576 \mathrm{E}-07$ & reduction of volume \\
\hline GK_2.7 & $1,67427 \mathrm{E}-09$ & \\
\hline
\end{tabular}

Table 1b: $K_{v}$ kept according to the mehod and the form of the seepage courve

\begin{tabular}{|c|c|}
\hline Horizons & $K_{v}(\mathrm{~m} / \mathrm{s})$ \\
\hline GK_0.1 & $4,422 \mathrm{E}-04$ \\
\hline GK_0.7 & $4,013 \mathrm{E}-06$ \\
\hline GK_1.0 & $2,012 \mathrm{E}-09$ \\
\hline GK_1.5 & $1,36 \mathrm{E}-07$ \\
\hline GK_2.7 & $1,674 \mathrm{E}-09$ \\
\hline
\end{tabular}

\section{GK_0.1= Sediment of the well GK at $0.1 \mathrm{~m}$ of depth}

i) Sediments GK_1.00 and GK_2.7 are not permeable (permeabilities of 2.012E-09 m/s and 1.674E-09 m/s);

ii) Sediment GK_ 1.5 have an intermediate permeability $(1,36 \mathrm{E}-07 \mathrm{~m} / \mathrm{s})$;

iii) The sediment GK_0.7 has a medium permeability of 4.0133.10-5 m/s. It is loamy sand. This permeability is weaker than that of the sediment GK_0.1 which is sandy and more permeable $(4.422 \mathrm{E}-04 \mathrm{~m} / \mathrm{s})$.

Measurementof the permeability in situ, by using the double Muntz ring:

Table 2 summarizes the results of in situ infiltration rate and permeabilities, using the Muntz double ring method at three depths that characterizes three different facies.

The averages infiltration rates at $0.35 \mathrm{~m}$ depth is $5,78 \mathrm{E}-06 \mathrm{~m} / \mathrm{s}$, thus characterizing a permeability of $1.21813 \mathrm{E}-05 \mathrm{~m} / \mathrm{s}$. These speeds decrease rapidly at the beginning (from 1 hour to 1 hour $+15 \mathrm{~min}$ ) and begin to fluctuate constantly until the end of the measurement, always remaining above E- $6 \mathrm{~m} / \mathrm{s}$.

The average infiltration rate at $0.7 \mathrm{~m}$ depth and $1 \mathrm{~m}$ are $5.50 \mathrm{E}-5 \mathrm{~m} / \mathrm{s}$ and $1.52 \mathrm{E}-6 \mathrm{~m} / \mathrm{s}$, characterizing a low permeability facies $(2,84513 \mathrm{E}-06$ and $5,27153 \mathrm{E}-07)$. This speed decreases rapidly at the beginning to about 1 hour $15 \mathrm{~min}$ and begins to fluctuate constantly until $2 \mathrm{~h} 30 \mathrm{~min}$ and to remain more or less constant until saturation, without reaching E-6m/s. The corespondant horizons are less permeable 
Citation:François de Paule CODO, 2018. Analyzis of permeabilities of the clayey sediments of Gbédji-Kotovi village in Benin for its valorization in the construction of dikes. Journal of Applied Sciences Research., 14(1): 45-56.

Table 2: Stocks of average infiltration rate measured in situ.

\begin{tabular}{|c|c|c|c|c|c|c|c|}
\hline Time t $(\mathrm{mm})$ & Section $\mathrm{S}$ & S.t & $\begin{array}{c}\text { Infiltration } \\
\text { Height }(\mathrm{cm})\end{array}$ & Time (s) & $\begin{array}{c}\text { Cumulative } \\
\text { time(s) }\end{array}$ & Infiltration & $\begin{array}{r}\text { Permeability } \\
K_{v}=\mathrm{V} /(\mathrm{S} . \mathrm{t})\end{array}$ \\
\hline \multicolumn{8}{|c|}{ Infiltration at $0,35 \mathrm{~m}$ of depth } \\
\hline 15 & 0,07065 & 1,05975 & 6 & 900 & 900 & $6,67 \mathrm{E}-05$ & $6,29394 \mathrm{E}-05$ \\
\hline 30 & 0,07065 & 2,1195 & 4 & 900 & 1800 & $4,44 \mathrm{E}-05$ & $2,09483 \mathrm{E}-05$ \\
\hline 45 & 0,07065 & 3,17925 & 3 & 900 & 2700 & $3,33 \mathrm{E}-05$ & $1,04742 \mathrm{E}-05$ \\
\hline 75 & 0,07065 & 5,29875 & 1 & 1800 & 4500 & $5,55 \mathrm{E}-06$ & $1,04742 \mathrm{E}-06$ \\
\hline 105 & 0,07065 & 7,41825 & 1 & 1800 & 6300 & $5,55 \mathrm{E}-06$ & $7,48155 \mathrm{E}-07$ \\
\hline 165 & 0,07065 & 11,65725 & 2,5 & 3600 & 9900 & $6,94 \mathrm{E}-06$ & $5,95338 \mathrm{E}-07$ \\
\hline 225 & 0,07065 & 15,89625 & 2,2 & 3600 & 13500 & $6,11 \mathrm{E}-06$ & $3,84367 \mathrm{E}-07$ \\
\hline 345 & 0,07065 & 24,37425 & 5,5 & 7200 & 20700 & 7,64E-06 & $3,13446 \mathrm{E}-07$ \\
\hline \multicolumn{6}{|c|}{ Average } & $5,78 \mathrm{E}-06$ & $1,21813 \mathrm{E}-05$ \\
\hline \multicolumn{8}{|c|}{ Infiltration at $0.70 \mathrm{~m}$ of depth } \\
\hline 10 & 0,07065 & 0,7065 & 8 & 600 & 600 & $1,33 \mathrm{E}-04$ & $3,21803 \mathrm{E}-06$ \\
\hline 20 & 0,07065 & 1,413 & 6,7 & 600 & 1200 & $1,12 \mathrm{E}-04$ & $2,31101 \mathrm{E}-06$ \\
\hline 30 & 0,07065 & 2,1195 & 4,3 & 600 & 1800 & $7,16 \mathrm{E}-05$ & $2,46896 \mathrm{E}-06$ \\
\hline 60 & 0,07065 & 4,239 & 3,1 & 1800 & 3600 & $1,72 \mathrm{E}-05$ & $2,68406 \mathrm{E}-06$ \\
\hline 100 & 0,07065 & 7,065 & 5 & 2400 & 6000 & $2,08 \mathrm{E}-05$ & $2,94515 \mathrm{E}-06$ \\
\hline 160 & 0,07065 & 11,304 & 18 & 3600 & 9600 & $5,00 \mathrm{E}-05$ & $3,26525 \mathrm{E}-06$ \\
\hline 220 & 0,07065 & 15,543 & 17 & 3600 & 13200 & $4,72 \mathrm{E}-05$ & $3,63422 \mathrm{E}-06$ \\
\hline 340 & 0,07065 & 24,021 & 12 & 7200 & 20400 & $1,66 \mathrm{E}-05$ & $2,56583 \mathrm{E}-06$ \\
\hline 580 & 0,07065 & 40,977 & 38 & 14400 & 34800 & $2,64 \mathrm{E}-05$ & $2,88656 \mathrm{E}-06$ \\
\hline \multicolumn{6}{|c|}{ Average } & $5,50 \mathrm{E}-05$ & $2,84513 \mathrm{E}-06$ \\
\hline \multicolumn{8}{|c|}{ Infiltration at $1 \mathrm{~m}$ of depth } \\
\hline 30 & 0,07065 & 2,1195 & 0,5 & 1800 & 1800 & $2,78 \mathrm{E}-06$ & $1,31 \mathrm{E}-06$ \\
\hline 30 & 0,07065 & 2,1195 & 0,4 & 1800 & 3600 & $2,22 \mathrm{E}-06$ & $1,05 \mathrm{E}-06$ \\
\hline 30 & 0,07065 & 2,1195 & 0,2 & 1800 & 5400 & $1,11 \mathrm{E}-06$ & $5,24 \mathrm{E}-07$ \\
\hline 60 & 0,07065 & 4,239 & 0,5 & 3600 & 9000 & $1,39 \mathrm{E}-06$ & $3,28 \mathrm{E}-07$ \\
\hline 60 & 0,07065 & 4,239 & 0,5 & 3600 & 12600 & $1,39 \mathrm{E}-06$ & $3,28 \mathrm{E}-07$ \\
\hline 120 & 0,07065 & 8,478 & 0,6 & 7200 & 19800 & $8,33 \mathrm{E}-07$ & 9,83E-08 \\
\hline 240 & 0,07065 & 16,956 & 1,3 & 14400 & 34200 & $9,028 \mathrm{E}-07$ & $5,32 \mathrm{E}-08$ \\
\hline \multicolumn{6}{|c|}{ Average } & 1,52.E-06 & $5,27153 \mathrm{E}-07$ \\
\hline \multicolumn{7}{|c|}{ Equivalent Coefficient of permeability Kve of the three multilayers } & $1,5372 \mathrm{E}-06$ \\
\hline
\end{tabular}

The synthesis of the infiltration velocities and the permeability of the first three horizons measured respectively at $0.35 \mathrm{~m}$; $0.7 \mathrm{~m}$ and $1 \mathrm{~m}$ of depthsare shown in the figures below:

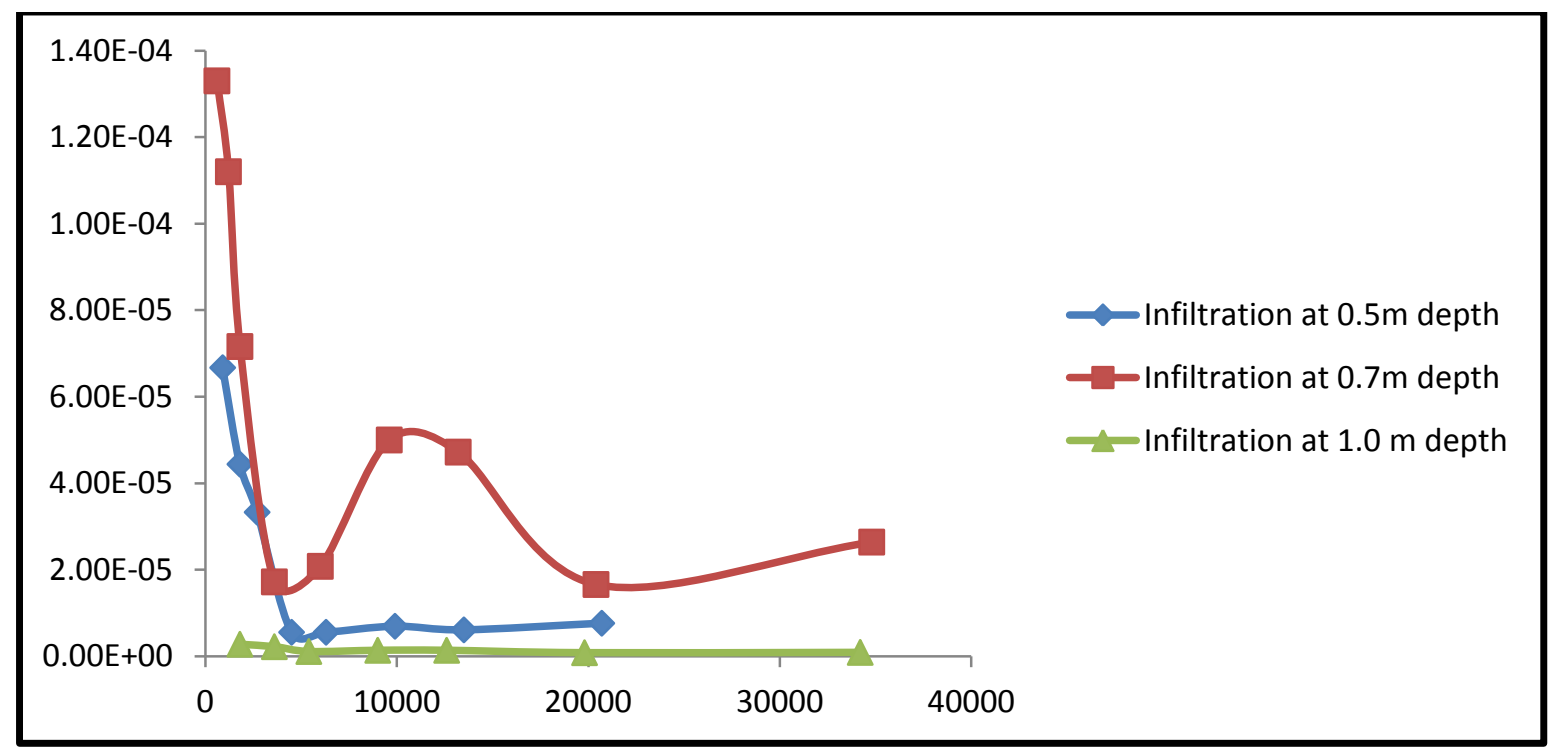

Fig. 7: Curves of infiltration rate of water in-situ as a function of time. 
Citation:François de Paule CODO, 2018. Analyzis of permeabilities of the clayey sediments of Gbédji-Kotovi village in Benin for its valorization in the construction of dikes. Journal of Applied Sciences Research., 14(1): 45-56.

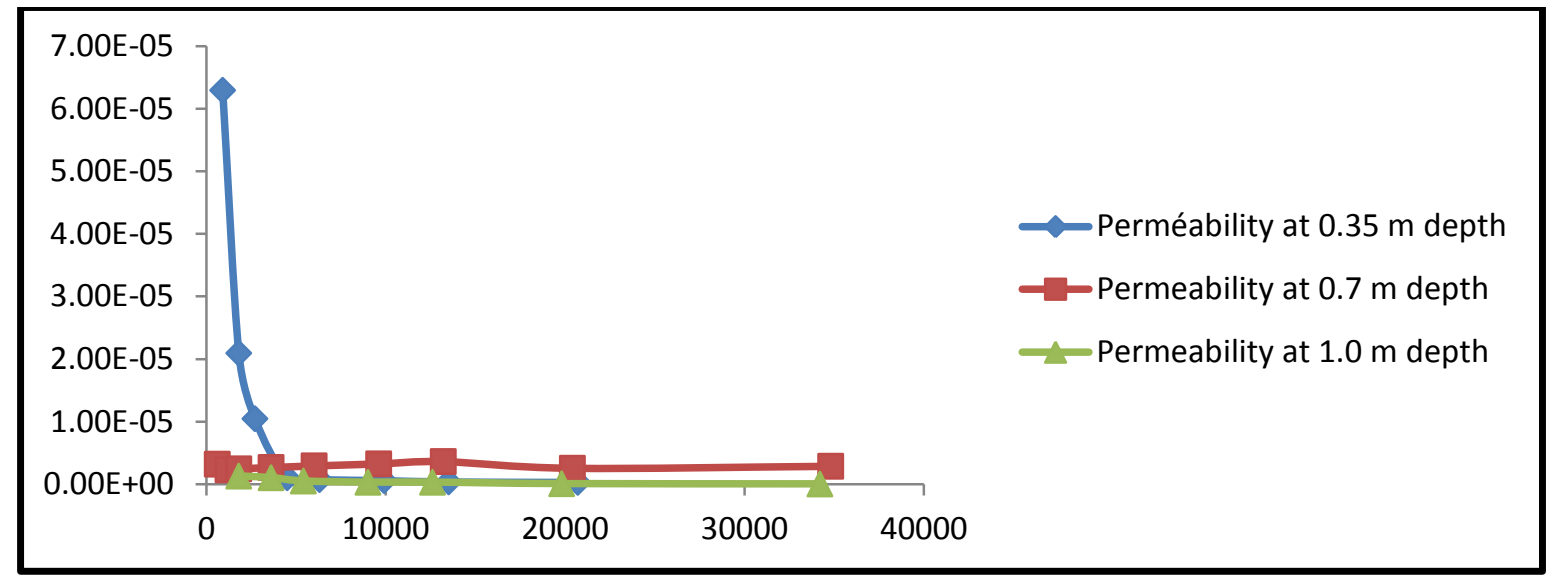

Fig.8: Curves of permeability in-situ, according to the depth, as a function of time.

Velocities of filtration and the permeabilities vary as a function of time. Overall, they are fast at the beginning of the measurements, up to $2 \mathrm{~h} 30 \mathrm{~min}$ and become weak until the end of the measurements:

At $0.35 \mathrm{~m}$ depth, the rate of infiltration tends constantly towards the saturation zone. The permeability decreases rapidly until $1 \mathrm{~h} 15$ minutes and becomes constant while remaining weak until the end of the measurement. It can be said that after saturation, the soil absorbs very little water, even if it is sandy.

At $0.70 \mathrm{~m}$ deph we note from 1hour, some fluctuations of filtration after 1hour, certainly due to anomalies that exist inside the horizon (presence of coarse grains, termites or rodent, dessicationetc.). The permeability is low at the beginning of the measurements and remains globally constant with the evolution of time.

At $1 \mathrm{~m}$ depth, the infiltration rate is low relative to the previous two levels. The permeability is low and constantly decreasing. This level is very clayey and compact.

Indirect measurement of permeability, by usingthe Oedometric method:

After loading-unloading-reloading the specimen, the sand behavior at $0.7 \mathrm{~m}$ is not elastic and has a hysteresis loop. Indeed, in the first part (loading) of this curve, the index of the voids of the sand, although initially low $\left(e_{0}=0.52\right)$ presents a more considerable variation. This is explained by the rearrangement of the grains. On the other hand, this variation is weak at unloading, because of the elastic deformation of the grains. Moreover, the unloading-reloading cycle of this sediment results in segments of lines almost confused or superimposed. This shows that the material resumes the same deformations during reloading. We can say that there was stabilization after the first deformations caused by the rearrangement of the grains. This behavior corresponds to a sand with fine and uniform granular structure (Magnan, 2000) whose void index only decreases by $8.72 \%$ after a maximum loading at the oedometer (907.6 KPa). The low recompression of the sediment $(\mathrm{Cs}=0.004)$ shows that it has an instantaneous and reversible behavior, in the absence of the applied loading. The oedometric compressibility curves of the sediments sampled at $0.7 \mathrm{~m} ; 1 \mathrm{~m} ; 1.5 \mathrm{~m}$ and $2.7 \mathrm{~m}$ (Figure 9) provide the mechanical parameters (Table 3) that made it possible to calculate the vertical permeabilities.

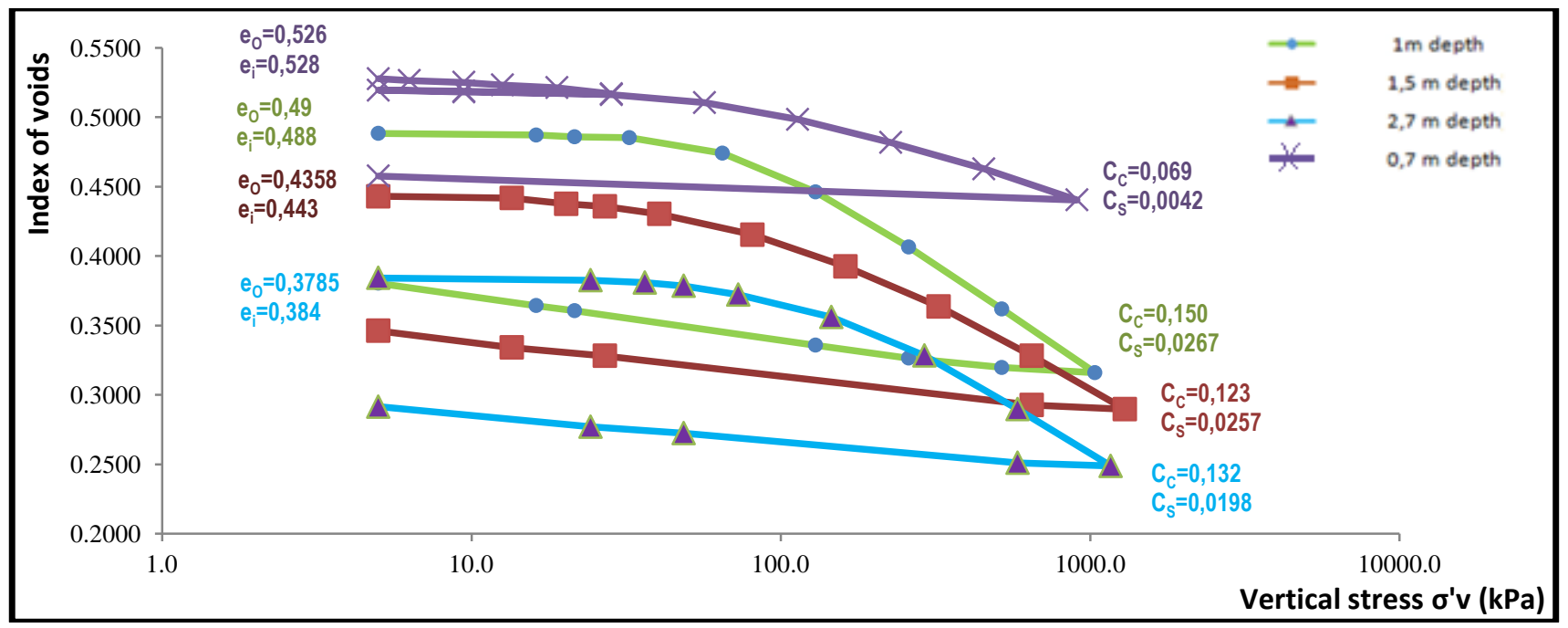

Fig. 9: Oedometric test of the sediments of different depths.

Modeling:

The model of Casagrande is used to calculate the indirect vertical permeability. In view of the inaccuracies related to the calculation of $C_{v}$ through the settlement curves, it is used the model of Taylor. 
Citation:François de Paule CODO, 2018. Analyzis of permeabilities of the clayey sediments of Gbédji-Kotovi village in Benin for its valorization in the construction of dikes. Journal of Applied Sciences Research., 14(1): 45-56.

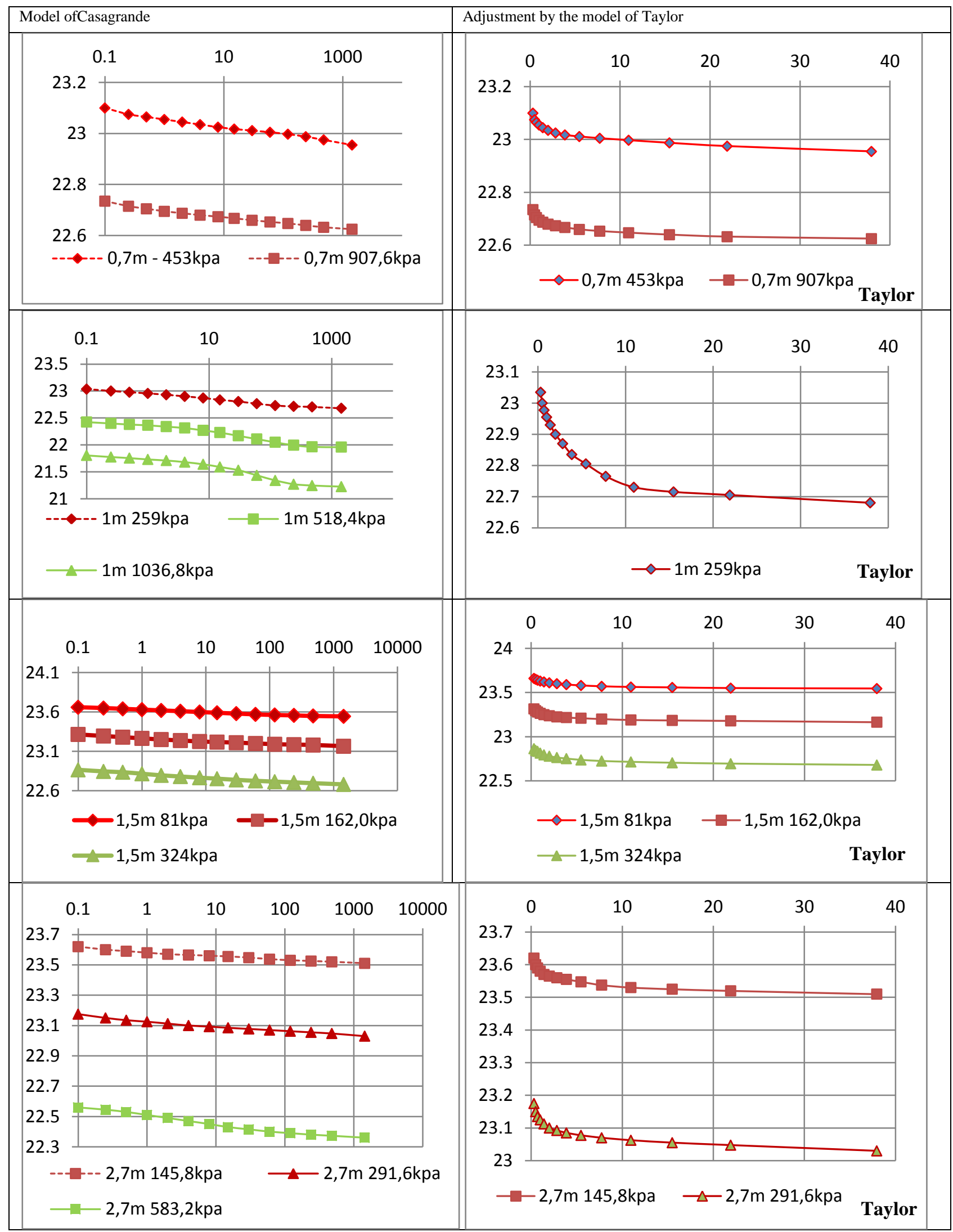

Fig. 10: Curves of casagrandemodel (left) and Taylor model (right).

Through the modeling withCasagrande and Taylor methods, the permeability values:

- vary between 1,178. E-10 and 3, 341.E-10 m/s for sandy sediments. These lower values are justified by the fact that the applied stresses are very high (453.8 $\mathrm{kPa}$ and $907.6 \mathrm{kPa}$ ). The small difference of permeability observed between $453.8 \mathrm{kPa}$ and $907.6 \mathrm{kPa}$ is explained by the arrangement of the solid grains between them, following the increase in stress.

- vary between 2.59 E-9 and 9.07.E-12 for clay sediments at $1 \mathrm{~m} ; 1.5 \mathrm{~m}$ and $2.7 \mathrm{~m}$ deep. It can be said that the clay sediments of these horizons are impermeable. In addition, some values $(2.01$, E-9 m/s, 1.29, 10-9 m/s, 2.59, E-9 m/s and 1.49)of permeabilities are relatively lower than $10-9 \mathrm{~m} / \mathrm{s}$. These values (Table 3 ) show that: 
Citation:François de Paule CODO, 2018. Analyzis of permeabilities of the clayey sediments of Gbédji-Kotovi village in Benin for its valorization in the construction of dikes. Journal of Applied Sciences Research., 14(1): 45-56.

i) There are heterogeneities (presence of large grains cracks) that can significantly promote permeability;

ii) The reduction of applied stresses leads to an increase in permeability.

Table 3: Main hydromechanicalparametersaccording to the oedometric test

\begin{tabular}{|c|c|c|c|c|c|c|c|c|c|c|c|}
\hline Depths & \multicolumn{2}{|c|}{$0,7 \mathrm{~m}$} & \multicolumn{3}{|c|}{$1 \mathrm{~m}$} & \multicolumn{3}{|c|}{$1,5 \mathrm{~m}$} & \multicolumn{3}{|c|}{$2,7 \mathrm{~m}$} \\
\hline$C_{c}$ & \multicolumn{2}{|c|}{0,0687} & \multicolumn{3}{|c|}{0,1503} & \multicolumn{3}{|c|}{0,1228} & \multicolumn{3}{|c|}{0,1322} \\
\hline$C_{s}$ & \multicolumn{2}{|c|}{0,004} & \multicolumn{3}{|c|}{0,0267} & \multicolumn{3}{|c|}{0,0257} & \multicolumn{3}{|c|}{0,0197} \\
\hline$\sigma_{v 0}^{\prime}(\mathrm{kPa})$ & \multicolumn{2}{|c|}{12,6} & \multicolumn{3}{|c|}{21,6} & \multicolumn{3}{|c|}{27} & \multicolumn{3}{|c|}{48,6} \\
\hline$\sigma_{p}^{\prime}(\mathrm{kPa})$ & \multicolumn{2}{|c|}{59} & \multicolumn{3}{|c|}{100} & \multicolumn{3}{|c|}{110} & \multicolumn{3}{|c|}{145} \\
\hline$\sigma_{v}^{\prime}$ & 453,8 & 907,6 & 259,2 & 518,4 & 1037,1 & 81 & 162 & 324 & 145,9 & 291,7 & 583,2 \\
\hline$C_{v} / \mathrm{E}^{-8}\left(\mathrm{~m}^{2} / \mathrm{s}\right)$ & 61,9 & 55,5 & 72,5 & 2,38 & 1,52 & 101 & 66 & 63,5 & 126 & 52,2 & 2,33 \\
\hline$K_{v} / \mathrm{E}-9(\mathrm{~m} / \mathrm{s})$ & 0,341 & 0,178 & 1,49 & 0,02478 & 0,00907 & 2,59 & 1,29 & 0,783 & 2,01 & 0,716 & 0,223 \\
\hline
\end{tabular}

It is noted that the model of Casagrande, on which is based the basic assumption is not usablein many cases, because the shape of the curve does not allow a precise graphical construction (Figure 10). In this case, the soil has a strong secondary compression, small increments of load and strongly consolidated $\left(C_{v}>\right.$ E-7). So, the model of Casagrande is suitable for high stress and the model of Taylor is well adapted for low or medium stresses. The difference observed in the sand is due to the fact that sands are hardly affected by the consolidation, so that the stress has practically no effect on the settlement. Finally, the modeling made it possible to calculateindirectly the coefficients of consolidation and vertical permeabilities. It can be said that the value of the permeability is mainly related to the void index and therefore to the stress exerted on the studied soil (Table 4). This decrease when the two parameters decrease and vice versa (Figure 11)

With the evolution of time, all Gbédji-Kotovi argillaceous sediments consolidate less and are less permeable when the applied stress increases. The maxima of consolidation and permeability are respectively observed at $2.7 \mathrm{~m}$ and $1.5 \mathrm{~m}$ under respective constraints of $145.9 \mathrm{kPa}$ and $81 \mathrm{kPa}$, while the minima are at $1 \mathrm{~m}$ depth under the effect of the stresses of $518 \mathrm{kPa}$ and $1037.1 \mathrm{kPa}$. The coefficients of consolidation and permeability decrease very little at $0.7 \mathrm{~m}$ depth because the index of the voids of the sands decrease very little with the increase of the stress and conversely, the permeability and the consolidation increase respectively with the increase of the index of the voids. On the other hand, it is found that the soils with the greatest index of voids (sands, for example) are not necessarily the most permeable, nor the most consolidated, if the applied stress reaches higher values.

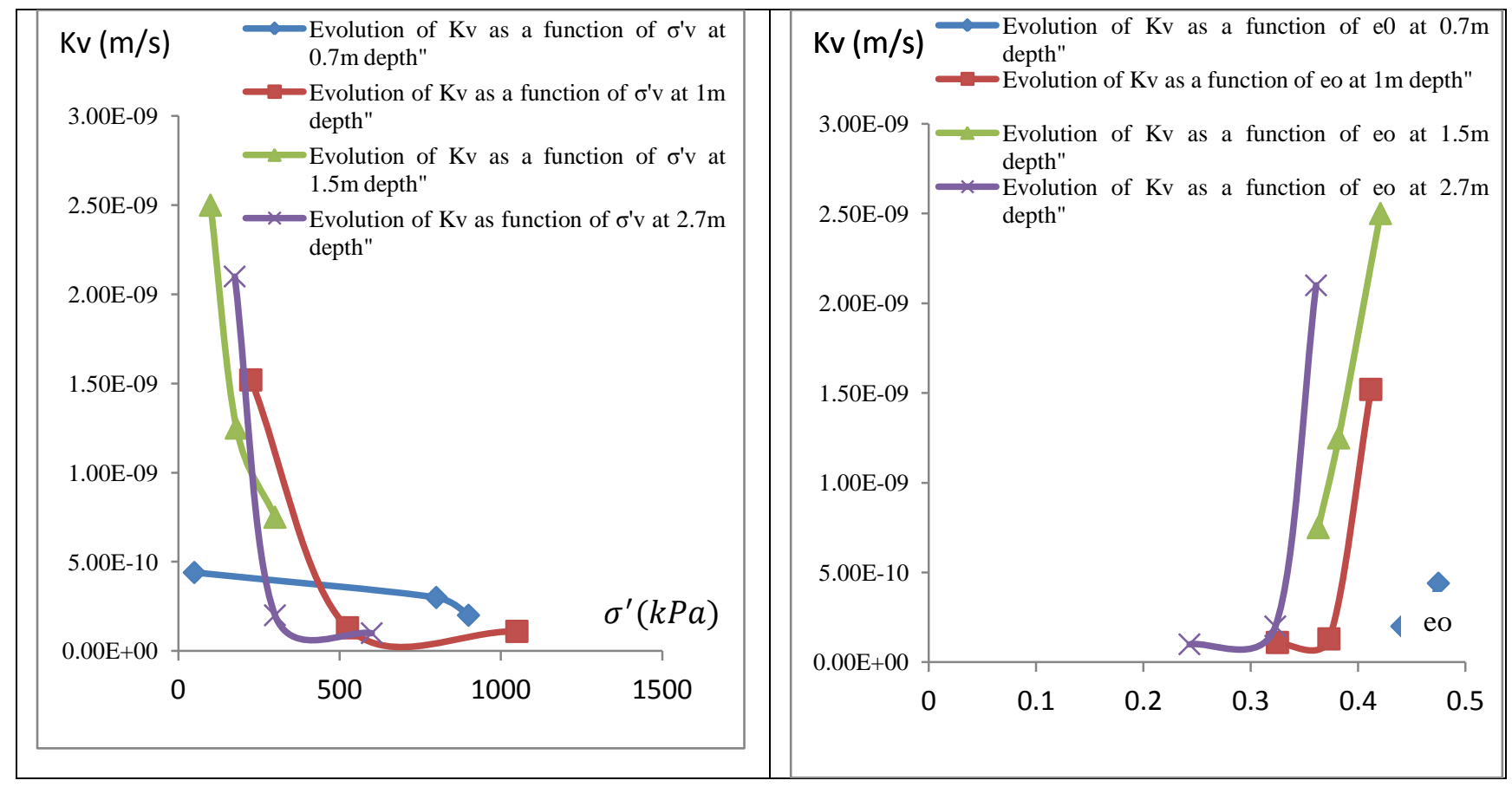

Fig. 11: Evolution of the vertical coefficient of permeability in function of the voids index and the vertical stress.

Table 4: Values of $K_{v}$ and $e_{0}$ measured vithoedometric test according to the depth.

\begin{tabular}{|c|c|c|c|}
\hline Depths (m) & $\sigma_{v}^{\prime}(\mathrm{kPa})$ & $e_{0}$ & $K_{v}$ \\
\hline \multirow[b]{3}{*}{0,7} & 50 & 0,475 & $0,44 \mathrm{E}-9$ \\
\hline & 800 & 0,465 & $0,30 \mathrm{E}-9$ \\
\hline & 900 & 0,441 & $0,20 \mathrm{E}-9$ \\
\hline \multirow{3}{*}{$1,00 \mathrm{~m}$} & 225 & 0,412 & $1,52 \mathrm{E}-9$ \\
\hline & 525 & 0,373 & $0,13 \mathrm{E}-9$ \\
\hline & 1050 & 0,325 & $0,11 \mathrm{E}-9$ \\
\hline \multirow{3}{*}{$1,5 \mathrm{~m}$} & 100 & 0,421 & $2,5 \mathrm{E}-9$ \\
\hline & 180 & 0,382 & $1,25 \mathrm{E}-9$ \\
\hline & 300 & 0,363 & $0,75 \mathrm{E}-9$ \\
\hline \multirow{3}{*}{$2,7 \mathrm{~m}$} & 175 & 0,361 & $2,1 \mathrm{E}-9$ \\
\hline & 300 & 0,323 & $0,20 \mathrm{E}-9$ \\
\hline & 600 & 0,243 & $0,10 \mathrm{E}-9$ \\
\hline
\end{tabular}

Since the design of watertight barriers is generally based on laboratory test results, it is demonstrated in this case that pre-construction design criteria will contribute to an underestimation of the soil hydraulic conductivity in-situ. This problem of underestimation of the hydraulic conductivity can be approached in several ways: 
Citation:François de Paule CODO, 2018. Analyzis of permeabilities of the clayey sediments of Gbédji-Kotovi village in Benin for its valorization in the construction of dikes. Journal of Applied Sciences Research., 14(1): 45-56.

- Macropores corresponding to larger voids between 10 and $50 \mu \mathrm{m}$ wide (at the interface of compacted lumps, the joints of building layers, shear surfaces or at the level of cracks caused by desiccation), may promote permeability even at the level of a layer of clay, especially in the field. This is consistent with the conclusions of Trautwein and BoutwelI (1994), which indicate that if the macroporosity is at least $1 \%$ of the total porosity, the overall hydraulic conductivity of a soil can increase by 100 times. In the case of Gbédji-Kotovi clays, we find that the deeper facies $(0.7 \mathrm{~m}$ deep) is more permeable than the shallower facies ( $0.35 \mathrm{~m}$ depth). This contrast is therefore justified by the presence of coarse gravels or cracks of desication.

- The actual hydraulic conductivity of a soil can be evaluated by testing larger samples. It means that testing a volume that will adequately represent the influence of macropores. This is partly responsible for the high values of permeability in-situ. Therefore, construction technics that seek to minimize the influence of macropores should be practiced in-situ. This will help to reduce the discrepancy between laboratory permeability tests and field tests, while improving the overall quality of the watertight barrier.

- The geological history and state of stress of a soil also have a primary role in measuring hydraulic conductivity. In this study, it is noted thatthe permeability decreases when the applied stress increases.

- Finally, we note that the hydraulic conductivity decreases respectively when going from a measurement in-situto a direct measurement through the infiltrometer in the laboratory and then to indirect estimation by the oedometric method.

- The permeability in-situhas fluctuations according to the depth. This fluctuation is due to macroporosity, cracks, and holes of insects or rodents. With the elimination of these heterogeneities progressively at the permeameter and the oedometer methods, it is found that the permeability of the Gbédji-Kotovi site gradually decreases and tends to stabilize with increasing depth.

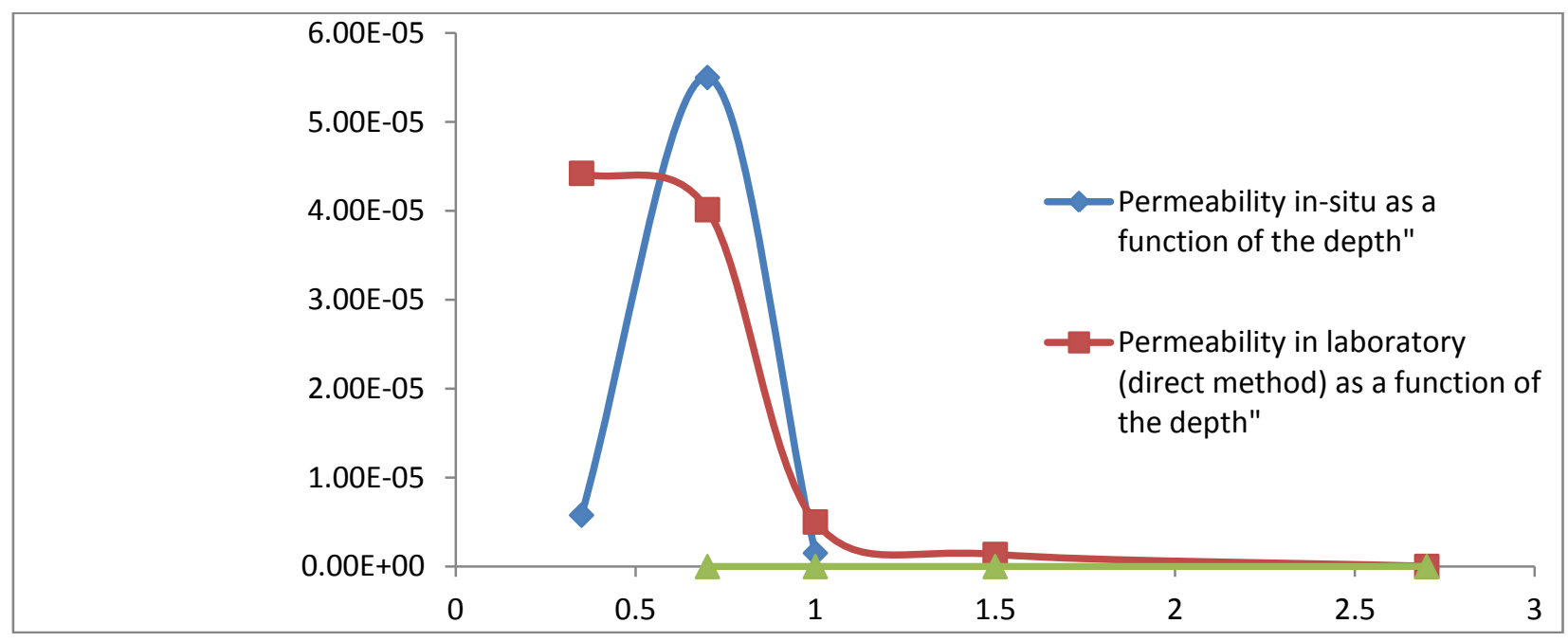

Fig. 12: Comparative curves of the evolution of the permeability by depth, using the three methods of measurement.

Permeability and infiltration of soils:

A hydraulic conductivity test (or permeability) conducted in-situ with equipment and the appropriate methodology is generally the most reliable approach to establishing a soil's ability to infiltrate the water. As an indication, Tables 5 and 6 provide orders of magnitude for hydraulic conductivity in different soils. As can be seen in Table 6, a safety factor should also be applied to the hydraulic conductivity values obtained with in-situ testing. So the permeability of clays usally have values between $10^{-8} \mathrm{~m} / \mathrm{s}$ and $10^{-10} \mathrm{~m} / \mathrm{s}$ (Gérard Degoutte et Paul Royet, 2009).

The most important factors that may affect the infiltration capacity of a soil are the natural slope of the soil, the type and properties of surface and subsurface soils, geological conditions, and hydrological conditions. The rate of infiltration is obviously greatly affected by the permeability of the soil in place. The infiltration rate for the first application of water during a test is generally greater. As the wetting continues and the upper part of the sediment becomes saturated, the rate of infiltration will gradually decrease and reach a more or less constant rate, usually after a few hours.

Table 5: Orders of magnitude of hydraulic conductivity in different soils according to Musy and Soutter (1991), quoted in Balan (2006).

\begin{tabular}{|l|c|c|c|c|c|}
\hline \multicolumn{2}{|c|}{ E-1 } & E-2 & E-3 & E-4 & E-5 \\
Soil type & $\begin{array}{l}\text { Gravel without sand } \\
\text { or fine elements }\end{array}$ & $\begin{array}{l}\text { Sand with gravel, } \\
\text { coars sand to fine } \\
\text { sand }\end{array}$ & $\begin{array}{l}\text { Very fine sand, coars silt } \\
\text { to clayey silt }\end{array}$ & $\begin{array}{l}\text { Silty clay to homogeneous } \\
\text { clay }\end{array}$ \\
\hline $\begin{array}{l}\text { Infiltration } \\
\text { possibilities }\end{array}$ & Excellent & Good & Medium to low & Low to zero \\
\hline
\end{tabular}

Table 6: Infiltration rate and typical hydraulic conductivity (adapted from Ferguson, 1994).

\begin{tabular}{|c|c|c|c|c|}
\hline \multirow[t]{2}{*}{ Soil type } & \multicolumn{2}{|c|}{ Saturated hydraulic conductivity } & \multicolumn{2}{|c|}{ Infiltration rate for design (safety factor of 0.5 ) } \\
\hline & $(\mathrm{mm} / \mathrm{h})$ & $(\mathrm{m} / \mathrm{s})$ & $(\mathrm{mm} / \mathrm{h})$ & $(\mathrm{m} / \mathrm{s})$ \\
\hline Sand & 210 & $5,83 \times \mathrm{E}-5$ & 105 & $2,92 \times \mathrm{E}-5$ \\
\hline siltysand & 61 & $1,69 \times 10-5$ & 30,5 & $8,45 \times$ E-6 \\
\hline Sandy Silt & 26 & $7,22 \times \mathrm{E}-6$ & 13 & $3,61 \times \mathrm{E}-6$ \\
\hline Limon & 13 & $3,61 \times$ E-6 & 6,5 & $1,81 \times \mathrm{E}-6$ \\
\hline Silty silt & 6,8 & $1,89 \times$ E-6 & 3,4 & $9,45 \times \mathrm{E}-7$ \\
\hline Clay-sandy loam & 4,3 & $1,19 \times \mathrm{E}-6$ & 2,2 & $5,95 \times \mathrm{E}-7$ \\
\hline Clay loam & 2,3 & $6,39 \times \mathrm{E}-7$ & 1,2 & $3,20 \times \mathrm{E}-7$ \\
\hline Clay-silty silt & 1,5 & $4,17 \times$ E-7 & 0,75 & $2,09 \times$ E-7 \\
\hline Sandy clay & 1,2 & $3,33 \times \mathrm{E}-7$ & 0,6 & $1,67 \times \mathrm{E}-7$ \\
\hline Siltyclay & 0,9 & $2,50 \times \mathrm{E}-7$ & 0,45 & $1,25 \times \mathrm{E}-7$ \\
\hline Clay & 0,6 & $1,67 \times$ E-7 & 0,3 & $8,35 \times \mathrm{E}-8$ \\
\hline
\end{tabular}


Conclusion:

One of the most important aspects to be considered in the sizing of an undercover work is to characterize the site where it is expected to be put in place. Although the rates of infiltration of existing soils can be assessed from values presented in the literature, it is always recommended to establish, in situ tests, the rate at which water can seep into the soil. The test provides higher results than those obtained by direct and indirect laboratory measurements, characterizing clayey limimons, clay-Sandy silts, Sands and silty sands. This type of in-situ test, combined with a characterization of the physical properties of the soil (texture, particle size, structure, relative density, etc.), will provide basic information to complete the hydraulic design of works such as dikes.The Taylor and Casagrande methods, which are based respectively on the settlement curves as a function of the square root and the logarithm of time (Standard AFNOR and LCPC) are applicable for our materials, but with deficiencies at each level. Indeed, it has not always been possible to linearise the curves correctly on $60 \%$ of the consolidation. For clay sediments, the Taylor model is preferable for high $C_{v}$ values $\left(C_{v}>\mathrm{E}-7 \mathrm{~m}^{2} / \mathrm{s}\right.$ to E- $\left.6 \mathrm{~m}^{2} / \mathrm{s}\right)$ and low stresses $(<500 \mathrm{kPa})$, whereas Casagrande is for low values of $C_{v}\left(C_{v}<\mathrm{E}-7 \mathrm{~m}^{2} / \mathrm{s}\right)$ and high stress (>500kPa). Regarding sand, the Taylor model is preferable whatever the stress and the coefficient of consolidation. The vertical permeability coefficient determined from the consolidation coefficient $\left(C_{v}\right)$ indicates impervious clays with average compressibility, swelling potentials and low permeabilities $\left(0,10.10^{-9} \mathrm{~m} / \mathrm{s}\right.$ to $\left.0,44.10^{-9} \mathrm{~m} / \mathrm{s}\right)$. The direct measurement of permeability in the laboratory on small sample sizes and the measurement in situ give relatively higher values than those obtained by the indirect method $\left(4.42 .10^{-5} \mathrm{~m} / \mathrm{s}\right.$ to $1,67.10^{-9} \mathrm{~m} / \mathrm{s}$ by using the Eijkelkamp opensystem permeameter with constant load or volume methods and $1,21.10^{-5} \mathrm{~m} / \mathrm{s}$ to $5,27.10^{-7} \mathrm{~m} / \mathrm{s}$ by using the Muntz double ring method). So the clayey sediments of Gbédji-Kotovi, in the case of their use in the construction of dikes, must be compacted (included their improvement by adding other sandy sediments) so as to avoid problems of instability, settlement, Shrinkage and swelling, G. PHILIPPONNAT, 1991). This improvement is said to reduce the permeability of dikes, about $10^{-8} \mathrm{~m} /$ sor less: Jean-Maurice Durand et al. (1999), Emmanuel ALONSO (2002)

\section{REFERENCES} 258

AZONTONDE, H.A., 1991 : Propriétés physiques et hydrauliques des sols au Bénin, Centre National d'Agro-Pédologie, BP 988, Cotonou, Bénin, pp: 250-

Boivin, P., Orstom Bondy, 1991. Caracterisation de l'infiltrabilité d'un sol par la mtthode Muntz,Variabilite de la mesure, pp : 70-74.

COLOMBANI, J., 1973. Mesure de la permeabilité des sols en place : un nouvel appareil pour la méthode MUNTZ, une extension dee la methode

PORCHET aux sols hétérogènes, pp: 197,198, 201-205, 224

Emmanuel ALONSO, 2002. Petits barrages, recommandations pour la conception, la réalisation et le suivi (chapitre IV, Barrages en remblai) ; Comité

Français des Grands Barrages, éditions CEMAGREF, pp: 68-69-70.

Etienne SAGBO, 2015. Characterization of Clay of the Benin Used in Ruminale Feeding. Complete Determination of the Smectites Contained in These

Clays, Journal of Environmental Protection, 2015, (6): 1322-1336

François Duhaime, 2012. Mesure de la conductivité hydraulique du dépôt d'argile champlain de lachenaie, québec: théorie et applications, pp : 196, 197,

198, 208, 490 .

Gérard Degoutte etPaul Royet, 2009: Aide mémoire de mécanique des sols, pp: 35.

Iheta, B., 1982. Rapport sur les recherches géologiques d'argiles dans la zone du Bassin Sédimentaire côtier du Bénin, Programme des Nations Unies pour le Développement; Projet : recherches minières au Bénin BEN/81/008

Jean-Maurice Durand Paul, 1999.Technique des petits barrages en afrique sahélienne et équatoriale, pp: 169-170.

Kassa Issifou MOUNOU SAMBIENI et Al., 2017. Characterization with geotechnical testings of the clay sediments of Gbédji-Kotovi in Benin, International Journal of Scientific \& Engineering Research, 8(12): 825- 834.

Luc Lepetit, 2002. étude d'une méthode de diagnostic de digues avec prise en compte du risque de liquefaction, thèse, pp: 43.

MARION PEREZ, 2013. Interprétation et modélisation numérique d'essais oedométriques et de perméabilité à niveau variable réalisés sur des argiles champlain, pp: 2, 28, 65,173.

Normalisation Française XP P94-090-1, 1997. Sols: reconnaissance et essai. Essai oedométrique, pp: 23.

PHILIPPONNAT, G.,1991. Shrinkage and swelling of clayey soils, proposal for methodology" Rev. Franç. Géotech. ${ }^{\circ} 57$, pp: 5-22.

SETRA- LCPC, 1992: Réalisation des remblais et couches de forme (GTR), Guide technique STREA-LCPC, 2 fascicules, 98 et, pp: 102. 